\title{
RELATIONS BETWEEN HYDROGEOLOGIC AND GEOELECTRIC PARAMETERS. A CASE STUDY: THE SETÚBAL PENINSULA, PORTUGAL (Preliminary results)
}

\author{
Rui M. D. Gonçalves *, A. R. Andrade Afonso ** and L. A. Mendes Victor \\ Departamento de Física, Faculdade de Ciências da Universidade de Lisboa \\ Rua da Escola Politécnica, 58, 1200 Lisboa, Portugal \\ georuias@skull.cc.fc.ul.pt*, np01vb@mail.telepac.pt**
}

\section{INTRODUCTION}

The Setúbal Peninsula is located southern of Lisbon City, in the midst of Portugal (fig. 1). This belt (area) belongs to the Tejo and Sado river basins and it's located between them. It comprises the most important aquifer system of the country. Geohydrological data from the thousand water extraction wells, and more than one hundred Vertical Electric Sounding (VES) surveys exist from that region (fig. 2). Merging of these different data yields better knowledge about constitution and protection of the system.

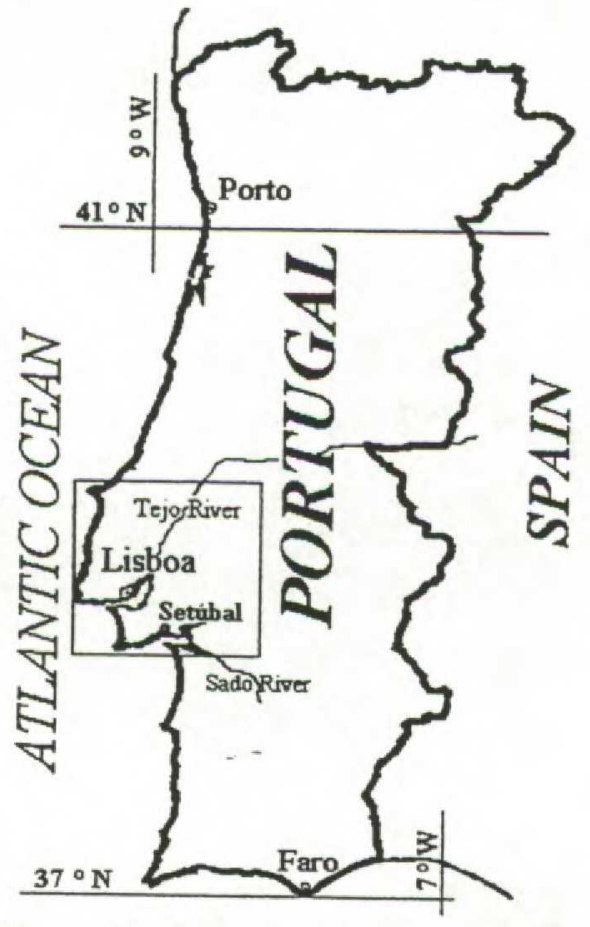

Figure 1 - Location of the survey area.

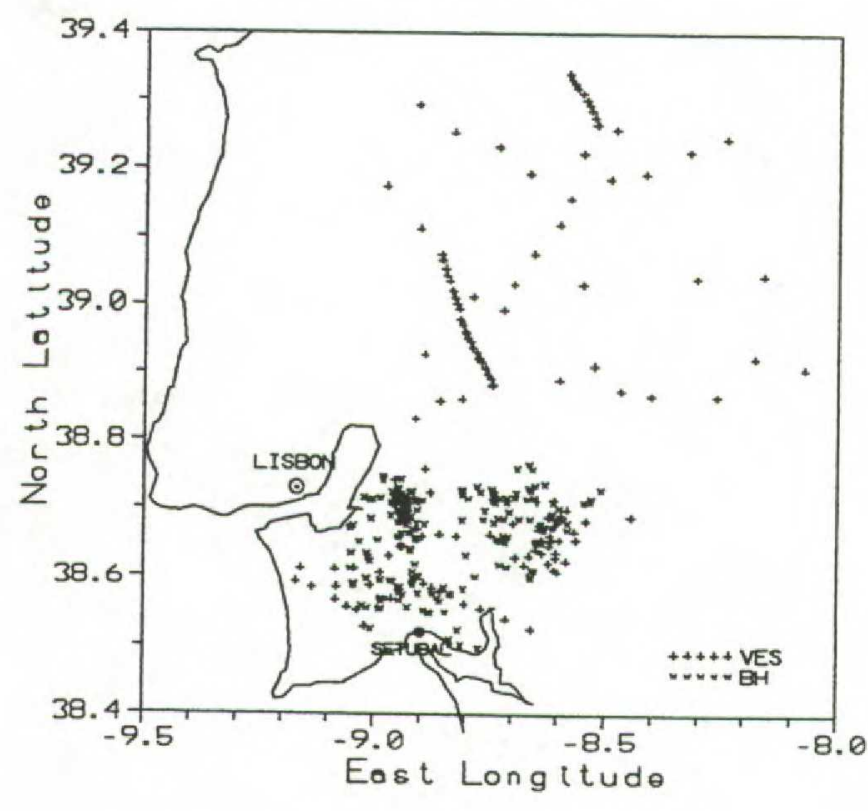

Figure 2 - Location of Boreholes and VES. 


\section{GEOHYDROLOGICAL CHARACTERISATION}

The aquifer system at Setúbal Peninsula has mainly three layers. Top to bottom, the first one is from Quaternary continental sediments, the second and third are from Pliocene and Miocene sediments. The mean depth of Miocene formation is about $200-300 \mathrm{~m}$, with a maximum depth of $700 \mathrm{~m}$ in the central zone of the peninsula and only $100 \mathrm{~m}$ at the eastern border. These Tertiary formations were formed from invasions and regressions of the sea, in a shallow lagoon, originating an alterning structure of sand and clay in the beginning of the Miocene. Clay extensions are not continuous, but form lenticular layers, which can have a thickness of several meters. The system is anisotropic and heterogeneous due to lateral variation of facies and different permeability values have been measured in the formations. Horizontal Transmissivity $(\mathrm{T})$ and Hydraulic Conductivity (K) exhibit a wide range of values. Water electrical resistivity is lower than $95 \Omega$.m (at $15^{\circ} \mathrm{C}$ ) for both Tertiary formations under consideration, but is slightly higher in the Pliocene. Saline intrusion is under way at both northern and southern boundaries of Setúbal's peninsula.

\section{LTTOLOGICAL, HYDROLOGICAL AND GEOELECTRICAL DATA}

A report is available for each water extraction facility. Most of them have litological information and some, hydrological parameters from pumping-tests. A few grain size data is also available. The litologic description is very important to know the percent clay layers content, and the type of sand in the Pliocene and Miocene formations. For each borehole, horizontal transmissivity, hydraulic conductivity and water resistivity are available for the depth extraction zone, located usually only in one litological unit (Pliocene or Miocene). The available Geoelectric data (VES) from old surveys were re-interpreted. A new survey was also performed. The AB/2 distance ranges from 500 to 2000 meters.

These geoelectric soundings yields resistivity and thickness information on the formations under study, that combined with previous described parameters, add more details to the knowledge of the aquifer system.

Figures 3 and 4, are respectively, the VES 15 and the borehole 445.005 litology (with comparing resistivity from VES 15 ). The distance between this borehole and VES 15 is $200 \mathrm{~m}$, and the respective data processing is presented as an example.

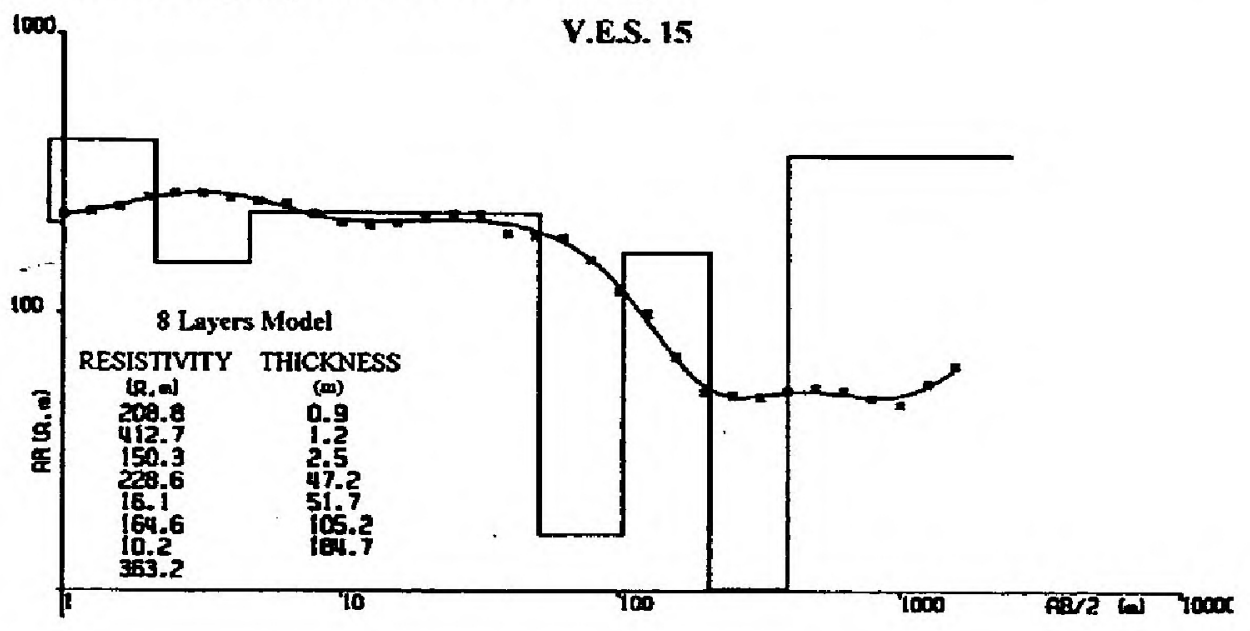

Figure 3 - VES 15. Field data points and corresponding 8 layers model. 


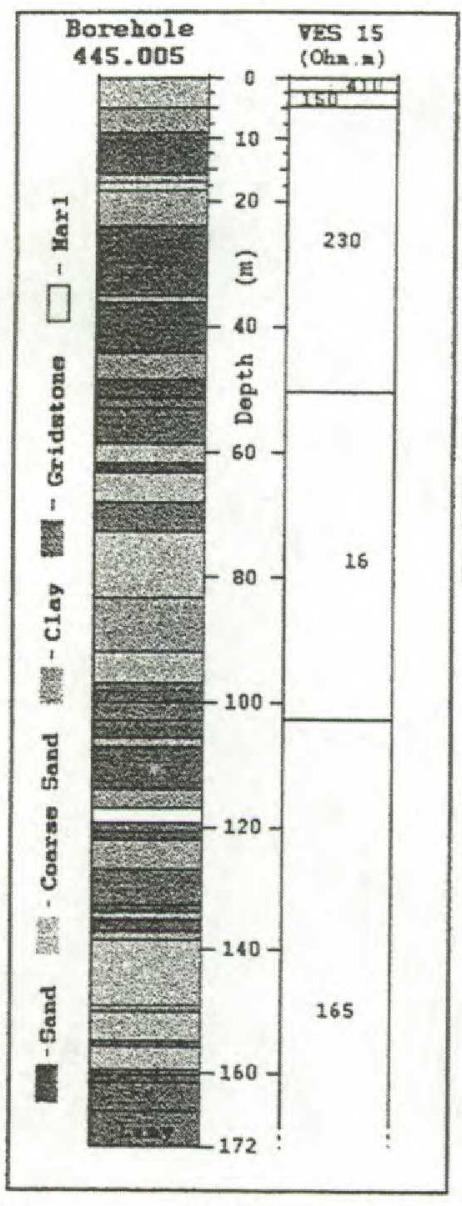

Table 1 - Hydrological parameters.

\begin{tabular}{|c|c|c|c|c|c|}
\hline Borehole & $\begin{array}{c}\mathrm{T} \\
\left(\mathrm{m}^{2} / \mathrm{d}\right)\end{array}$ & $\begin{array}{c}\mathrm{K} \\
(\mathrm{m} / \mathrm{d})\end{array}$ & $\begin{array}{c}\text { Water Resistivity } \\
(\Omega . \mathrm{m})\left(\text { at } 15^{\circ} \mathrm{C}\right)\end{array}$ & $\begin{array}{c}\text { Layers } \\
\text { Clay }(\%)\end{array}$ & $\begin{array}{c}\text { Depth } \\
(\mathrm{m})\end{array}$ \\
\hline 445.005 & 4000 & 130 & 61 & 21 & $92-161$ \\
\hline
\end{tabular}

Table 2 - Geoelectric and resulting formation parameters.

\begin{tabular}{|c|c|c|c|c|}
\hline VES & $\begin{array}{c}\text { Layer 6 } \\
(\Omega . \mathrm{m})\end{array}$ & $\begin{array}{c}\text { Sand } \\
(\Omega . \mathrm{m})\end{array}$ & $\mathrm{F}$ & $\begin{array}{c}\text { Porosity } \\
(\%)\end{array}$ \\
\hline 15 & 165 & 350 & 8.8 & 19 \\
\hline
\end{tabular}

Table 1 resumes data from borehole 445.005. This data merged with geoelectric data from VES 15 (table 2), corrected for clay layers content (Schlumberger Lda, 1969), gives us a corresponding sand layer resistivity of $350 \Omega . \mathrm{m}$. The apparent formation factor is give by:

$$
\mathrm{F}_{\mathrm{a}}=\rho_{\mathrm{s}} / \rho_{\mathrm{w}}
$$

$\rho_{s}$ - sand resistivity ( $\left.\Omega . \mathrm{m}\right), \rho_{w}$ - water resistivity $(\Omega . \mathrm{m})$

$\mathrm{F}_{\mathrm{a}}=350 / 61=5.7$

The formation factor is obtained from the following relation:

Figure 4 - Litology and VES.

$$
\frac{1}{\mathrm{~F}_{a}}=\frac{1}{\mathrm{~F}}+\frac{\rho_{w}}{\rho_{m}}
$$

F - formation factor, $\rho_{m}$ - formation matrix resistivity, assumed value (1000 $\left.\Omega . m\right)$ (Huntley, 1987)

To obtain formation porosity values, Archie equation (Kwader, 1986) was used:

with;

$$
\mathrm{F}=\mathbf{a} \phi^{-m}
$$

a - pore geometry coefficient, assumed 1 for granular systems in Tertiary formation

$\mathrm{m}$ - cementation factor, equal to 1.3 in Pliocene-Miocene sands

The achieved formation factor of 8.8 (19\% of porosity), the hydraulic conductivity of $130 \mathrm{~m} / \mathrm{d}$ and the grain size of $0.5 \mathrm{~mm}\left(\mathrm{D}_{50}\right)$ for the formations of this zone, are in good agreement with available data presented by other authors (Kelly W.E., 1978; Shepherd, 1989).

\section{DATA ANALYSIS}

This procedure was performed trough all available data. A great dispersion in the values is seen, when all data are considered. So, we must divide the area under survey into smaller zones to find 
local characteristics. The grid in figure 5 is a set of 1:25.000 scale maps covering the study area, each map having $16 \times 10 \mathrm{Km}$. Table 3 is a summary of mean values for each map.

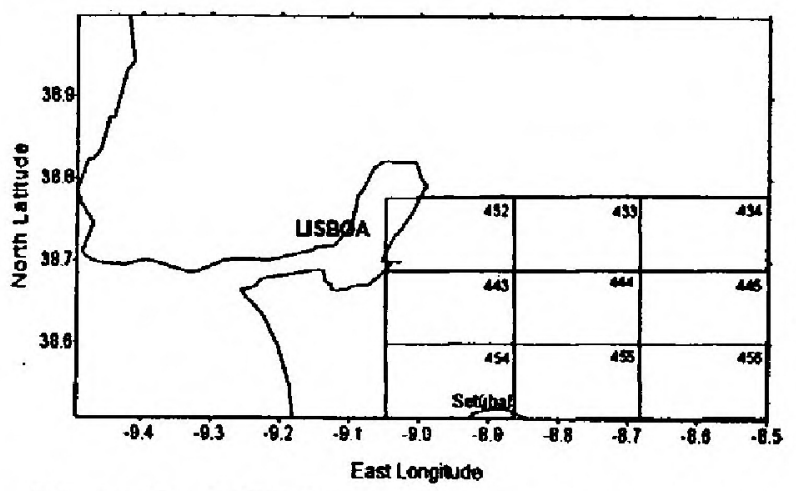

We found that $K$ is smaller in the north-eastern zone and have larger values at the central one. The porosity decreases from NE to W-SW. In the middle of the peninsula (map 443) a simple relation exists (almost linear) between the hydraulic conductivity and the formation factor;

$$
K=9.5 F^{0.93}
$$

Figure 5 - 1:25.000 scale maps at study area.

Table 3 - Mean values of the parameters for each map.

\begin{tabular}{|c|c|c|c|c|c|c|c|}
\hline Map & $\begin{array}{c}\mathrm{T} \\
\left(\mathrm{m}^{2} / \mathrm{d}\right)\end{array}$ & $\begin{array}{c}\mathrm{K} \\
(\mathrm{m} / \mathrm{d})\end{array}$ & $\begin{array}{c}\text { Water Res. } \\
(\Omega \cdot \mathrm{m})\end{array}$ & $\begin{array}{c}\text { Layer Res. } \\
(\Omega \cdot \mathrm{m})\end{array}$ & $\begin{array}{c}\text { Sand Res. } \\
(\Omega . \mathrm{m})\end{array}$ & $\mathrm{F}$ & $\begin{array}{c}\text { Porosity } \\
(\%)\end{array}$ \\
\hline 432 & 650 & 29 & 34 & 65 & 140 & 7.0 & 24 \\
\hline 433 & 366 & 12 & --- & 120 & 210 & ---- & --- \\
\hline 434 & 420 & 16 & 67 & 75 & 140 & 3.5 & 38 \\
\hline 443 & 700 & 39 & 50 & 95 & 195 & 6.7 & 24 \\
\hline 444 & 830 & 34 & 72 & 110 & 250 & 7.0 & 21 \\
\hline 445 & 320 & 10 & 39 & 80 & 170 & 3.3 & 25 \\
\hline 454 & 254 & 17 & 33 & 75 & 140 & 10.5 & 15 \\
\hline 455 & 530 & 33 & 65 & 125 & 210 & 9.0 & 14 \\
\hline
\end{tabular}

\section{REFERENCES}

Huntley, D. 1987. Relations Between Permeability and Electrical Resistivity in Granular Aquifers. Ground Water. v. 24, no. 4, pp. 466-474.

Kelly, W. 1978. Geoelectric Sounding for Estimating Aquifer Hydraulic Conductivity. Ground Water. v. 15 , no. 6, pp. 420-425.

Kwader, T. 1986. Estimating Aquifer Permeability from Formation Resistivity Factors. Ground Water. v. 23 , no. 6 , pp. $762-766$.

Schlumberger Lda. 1969. Log Interpretation Principles

Shepherd, R. G. 1989. Correlations of Permeability and Grain Size. Ground Water. v. 27, no. 5, pp. 633-638.

Acknowledgements: We thank the Portuguese Water Institute and namely M. Sérgio Lopes for the cession of resistivity field data.

This work is performed under the scope of the project "Capacidade de Carga do Ecossistema em Aquiferos Costeiros", sponsored by the "PRAXIS XXI" program. 